\title{
Population dynamics of the endangered mountain ecotype of woodland caribou (Rangifer tarandus caribou) in British Columbia, Canada
}

\author{
Heiko U. Wittmer, Bruce N. McLellan, Dale R. Seip, James A. Young, \\ Trevor A. Kinley, Glen S. Watts, and Dennis Hamilton
}

\begin{abstract}
We used census results and radiotelemetry locations of $>380$ collared individuals sampled over the entire distribution of the endangered mountain ecotype of woodland caribou (Rangifer tarandus caribou (Gmelin, 1788)) in British Columbia, Canada, to delineate population structure and document the size and trend of the identified populations. We also describe the spatial pattern of decline and the causes and timing of adult mortality and provide estimates of vital rates necessary to develop a population viability analysis. Our results indicate that the abundance of mountain caribou in British Columbia is declining. We found adult female annual survival rates below annual survival rates commonly reported for large ungulates. The major proximate cause of population decline appears to be predation on adult caribou. Spatial patterns of population dynamics revealed a continuous range contraction and an increasing fragmentation of mountain caribou into smaller, isolated subpopulations. The population fragmentation process predominantly occurs at the outer boundaries of the current distribution. Our results indicate that recovery strategies for mountain caribou should be directed at factors contributing to the fragmentation and isolation of mountain caribou populations as well as management strategies aimed at increasing adult survival.
\end{abstract}

Résumé : Des données d'inventaire et des coordonnées obtenues par radiotélémétrie pour >380 individus munis de colliers émetteurs provenant de toute l'aire de répartition de l'écotype menacé du caribou de montagne (Rangifer tarandus caribou (Gmelin, 1788)) en Colombie-Britannique, Canada, nous ont servi à décrire la structure des populations et déterminer la taille et la tendance des populations identifiées. Nous décrivons aussi le pattern spatial du déclin et les causes et la phénologie de la mortalité des adultes et nous fournissons des estimations des taux vitaux requis pour faire une analyse de viabilité de la population. Nos résultats indiquent un déclin de l'abondance des caribous de montagne en Colombie-Britannique. Les taux annuels de survie des femelles adultes sont inférieurs à ceux qui sont couramment signalés chez les grands ongulés. La cause principale immédiate du déclin de la population semble être la prédation subie par les caribous adultes. Les patterns spatiaux de la dynamique de la population indiquent une réduction constante de l'aire de répartition et une fragmentation croissante des caribous de montagne en sous-populations plus petites et isolées. Le processus de fragmentation de la population se produit aux limites externes de la répartition actuelle. Nos résultats indiquent que les stratégies de récupération du caribou de montagne doivent cibler les facteurs qui contribuent à la fragmentation et à l'isolement des populations de caribous de montagne, en plus de mettre sur pied des stratégies de gestion propres à augmenter la survie des adultes.

[Traduit par la Rédaction]

\section{Introduction}

The distribution of woodland caribou (Rangifer tarandus caribou (Gmelin, 1788)) has contracted across North Amer- ica following human settlement (Bergerud 1974), but predation is generally considered the proximate limiting factor across most of the distribution (Bergerud and Elliot 1986; Seip 1992; Bergerud 1996; Stuart-Smith et al. 1997; Rettie

Received 25 November 2004. Accepted 10 March 2005. Published on the NRC Research Press Web site at http://cjz.nrc.ca on 7 May 2005.

H.U. Wittmer. ${ }^{1,2}$ Agroecology, Faculty of Agricultural Sciences, University of British Columbia, 2357 Main Mall, Vancouver, BC V6T 1Z4, Canada.

B.N. McLellan. Ministry of Forests, Research Branch, P.O. Box 9158, RPO \#3, Revelstoke, BC V0E 3K0, Canada.

D.R. Seip. Ministry of Forests, 1011-4th Avenue, Prince George, BC V2L 3H9, Canada.

J.A. Young. Ministry of Water, Land and Air Protection, Suite 400, 640 Borland Street, Williams Lake, BC V2G 4T1, Canada.

T.A. Kinley. Sylvan Consulting Ltd., RR5 3519 Toby Creek Road, Invermere, BC V0A 1K5, Canada.

G.S. Watts. Ministry of Water, Land and Air Protection, 1011-4th Avenue, Prince George, BC V2L 3H9, Canada.

D. Hamilton. Nanuq Consulting Ltd., 512 West Innes Street, Nelson, BC V1L 3J3, Canada.

${ }^{1}$ Corresponding author (e-mail: wittmer@xtra.co.nz).

${ }^{2}$ Present address: Department of Environmental Science, Policy and Management, University of California, Berkeley, CA 947203110, USA. 
and Messier 1998; Schaefer et al. 1999). Predation may be facilitated by logging and other changes to caribou habitat that favour early seral stage forest (Rettie and Messier 1998). These young forest stands are thought to promote higher densities of alternative prey species such as moose (Alces alces (L., 1758)), which in turn support higher predator densities (Bergerud and Elliot 1986; Seip 1992). In addition, linear corridors associated with industrial operations in forested areas may increase the speed and range of predator movements and thus result in increased predation on caribou (James and Stuart-Smith 2000). Because of declining population trends and increasing population fragmentation with the continued spread of managed forests, conservation of woodland caribou has become a significant concern across much of their distribution in Canada (Thomas and Gray 2002).

Woodland caribou within the Southern Mountains National Ecological Area of Canada are considered "threatened" by the Committee on the Status of Endangered Wildlife in Canada (COSEWIC 2002). A subgroup of these caribou, the mountain ecotype (referred to as mountain caribou) found in the interior wet belt of British Columbia (Heard and Vagt 1998), are considered "endangered" in British Columbia and also in Idaho, where they are the last remaining caribou in the United States outside Alaska (US Fish and Wildlife Service 1994; British Columbia Conservation Data Centre 2001). The distribution of mountain caribou in British Columbia has declined over the past century (Seip and Cichowski 1996; Spalding 2000); they are now found in only 12 recognized subpopulations, some of which are contiguous while others appear isolated (Heard and Vagt 1998).

Mountain caribou are closely associated with latesuccessional, coniferous forests (Rominger and Oldemeyer 1989; Apps et al. 2001). Their primary winter food, arboreal lichen (Bryoria spp. and Alectoria sarmentosa (Ach.) Ach.), is abundant in these forests (Rominger and Oldemeyer 1989; Rominger et al. 1996; Terry et al. 2000). In contrast to other woodland caribou in North America, mountain caribou walk on top of the deep snowpack (generally $>2 \mathrm{~m}$ ) in the mountains to gain access to lichen in the forest canopy. Many of these old forests are highly valuable to the forest industry and thus there is considerable interest in integrating forest management and mountain caribou habitat requirements (Stevenson et al. 2001).

The objectives of this study are to objectively delineate the remaining subpopulations of mountain caribou in British Columbia and document their size, trend, pregnancy and recruitment rates, and causes and temporal distribution of adult mortality. The South Selkirks subpopulation along the British Columbia - Idaho border is excluded because of the long history of augmentation of this subpopulation (Compton et al. 1995). We have three goals in presenting these demographic data. The first is to document the structure and dynamics of an endangered ungulate population to enable a greater understanding of the pattern of population decline and to provide estimates of vital rates that are critical to population viability analyses. The second goal is to present long-term data on the population dynamics of a large herbivore based on an extensive sample of marked individuals in an ecosystem with a full complement of five natural predators, because such data are particularly scarce (Gaillard et al.
2000). Finally, data on the population distribution and dynamics of an endangered herbivore should enable managers to focus attention where it is most immediately needed to preserve this ecotype of caribou.

\section{Methods}

\section{Study area}

Mountain caribou are found in southeastern British Columbia and northern Idaho from near the international border at $49^{\circ} \mathrm{N}$ to northeast of Prince George at about $55^{\circ} \mathrm{N}$. Their distribution in 1999 encompassed approximately $58500 \mathrm{~km}^{2}$ (Stevenson et al. 2001) of mostly mountainous terrain, with elevation varying from about $400 \mathrm{~m}$ to $>3500 \mathrm{~m}$. Northern portions of this range are generally characterized by highland topography with sloping plateaus and rounded mountains. Mountains in more southerly and eastern portions of the distribution are generally higher and more rugged. Although climate varies across the distribution, the influence of Pacific air masses results in high annual precipitation, most of which falls as snow during winter (Environment Canada 2002). The cool, wet climate results in low frequency and extent of natural fire disturbance, and thus forests are naturally dominated by old age classes (Meidinger and Pojar 1991).

Mountain caribou are found primarily in four biogeoclimatic zones. In the southern portion of the mountain caribou range, lower elevation habitats are within the Interior Cedar Hemlock (ICH) biogeoclimatic zone (Meidinger and Pojar 1991). Climax ICH forests are dominated by western redcedar (Thuja plicata Donn ex D. Don) and western hemlock (Tsuga heterophylla (Raf.) Sarg.). A moderately developed shrub layer commonly includes black huckleberry (Vaccinium membranaceum Dougl. ex Torr.) and boxleaf (Paxistima myrsinites (Pursh) Raf.). In the northern portion of the mountain caribou range, the ICH is replaced by the SubBoreal Spruce (SBS) biogeoclimatic zone. Climax SBS forests are dominated by white spruce (Picea glauca (Moench) Voss) and subalpine fir (Abies lasiocarpa (Hook.) Nutt.) Common shrubs are black huckleberry, birch-leafed spirea (Spiraea betulifolia Pallas), and thimbleberry (Rubus parviflorus Nutt.). At mid elevations, above the ICH and SBS, is the Engelmann Spruce - Subalpine Fir (ESSF) biogeoclimatic zone. Climax ESSF forests are dominated by Engelmann spruce (Picea engelmannii Parry ex Engelm.) and subalpine fir. The shrub layer contains varying amounts of black huckleberry, white-flowered rhododendron (Rhododendron albiflorum Hook.), black gooseberry (Ribes lacustre (Pers.) Poir.), and oval-leaf blueberry (Vaccinium ovalifolium Sm.). High elevations are in the Alpine Tundra (AT) biogeoclimatic zone, where trees are absent. Vegetation in the AT consists of a variety of shrubs, grasses, sedges, herbs, bryophytes, and lichens, which are often widely separated by areas of bare soil, rock, or glaciers. Forestry is the dominant land-use activity across the range of mountain caribou, and clear-cutting and replanting is the most common silvicultural system used.

Mountain goats (Oreamnos americanus (de Blainville, 1816)) and moose are found throughout the range of mountain caribou, with moose being rarer in southern areas. White-tailed deer (Odocoileus virginianus (Zimmermann, 
1780)), mule deer (Odocoileus hemionus (Rafinesque, 1817)), and elk (Cervus elaphus L., 1758) are abundant in southern areas. Common predators across the distribution of mountain caribou include grizzly bear (Ursus arctos L., 1758), black bear (Ursus americanus Pallas, 1780), and wolverine (Gulo gulo (L., 1758)), while wolves (Canis lupus L., 1758) are more abundant in the north and cougar (Puma concolor (L., 1771)) are more abundant in the south. Mountain caribou are no longer legally hunted, although a limited number of permits were issued to shoot males until the mid-1990s in some areas (Hatter et al. 2002).

\section{Animal capture and telemetry}

Between 1984 and 2004, 386 adult caribou (338 females, 48 males) were captured using a net gun fired from a helicopter in open subalpine habitat during late winter (Table 1). The sample of collared animals had a geographic distribution that approximated that of mountain caribou in British Columbia because a high proportion of the population is visible and available for capture at this time of year. All captured caribou were fitted with either mortality/motionsensitive very high frequency (VHF) conventional radio collars or Global Positioning System (GPS) collars with VHF signals and mortality/motion sensors.

Telemetry relocations were recorded from fixed-wing aircraft 2-4 times each month. Locations were plotted on aerial photographs or topographic maps and the Universal Transverse Mercator (UTM) coordinates of each animal were recorded to the nearest $100 \mathrm{~m}$. When the technology became available, a GPS in the aircraft was also used to place located animals. GPS collars were programmed to attempt a fix every 4-6 h. The number of fixes obtained per caribou differed between the two types of telemetry collars. We therefore extracted a random subsample of GPS fixes at 2week intervals to match VHF standards for our analysis.

\section{Subpopulation delineation}

We used the telemetry data to examine subpopulation boundaries and estimate the area occupied by each subpopulation following the methods of Rettie and Messier (1998). Multi-annual, $100 \%$ minimum convex polygon (MCP) (Mohr 1947) home ranges, or the maximum areas that individuals were known to cover, were delineated using the animal movement extension (Hooge and Eichenlaub 2000) in ArcView $^{\circledR}$ (ESRI 1996). We plotted the MCP home ranges of all collared animals and placed each individual in a specific subpopulation when its MCP home range overlapped that of at least one other member of the subpopulation. Subpopulations were separated where no MCP home ranges of collared animals occurred, although it is possible that some animals moved among subpopulations. We then pooled telemetry locations among animals within each subpopulation and delineated the subpopulation's boundaries and area using a 95\% fixed kernel approach (Worton 1989).

\section{Subpopulation size and trend}

Between 1992 and 2004, caribou subpopulations were censused at irregular intervals in March or early April, when caribou are in open, high-elevation habitats, shortly after new snow fell, using Bell 206 helicopters. In mountainous terrain, a pilot and two or three observers flew contours along the forest-subalpine habitat boundary, whereas in plateau habitats the numerous forest openings were searched for caribou tracks. Fresh tracks were followed until the animals were sighted, unless the tracks descended into mature timber and were lost from view. When caribou were encountered they were easily enumerated, as median group size was only five animals. Caribou were classified as adult males, adult females, or calves. In forested areas where close examination was not always possible, antlered females were sometimes difficult to distinguish from young males and classification was often limited to adults and calves only. We confirmed the presence of radio-collared animals by scanning groups for known collar frequencies. Radio collars, however, were used as marks and not to locate animals. When available, the location of the sighting was recorded using a GPS in the helicopter, and locations were also recorded on topographic maps. Survey areas and boundaries were adjusted slightly based on changes in observed animal distribution.

Population estimates and $95 \%$ confidence intervals were derived using the joint hypergeometric maximum likelihood estimator (JHE) (Bartmann et al. 1987) in the NOREMARK computer program (White 1996). In cases where the lower 95\% confidence limit was below the actual number of caribou seen during census flights, we used the census result as the lower confidence limit. Some subpopulations were small and thus there were too few radio-collared animals to estimate population size using the proportion of marked animals that were observed (i.e., sightability). In these cases we calculated a correction factor that was the proportion of all collared animals in all subpopulations over all years that were observed during censuses. We used log-likelihood ratios (Zar 1999) to determine whether sightability of collared caribou during population censuses differed among years.

We then calculated the finite rate of population increase, $\lambda$, adjusted to a yearly time interval as

$$
\lambda=\left(N_{t} / N_{0}\right)^{1 / t}
$$

where $N_{t}$ is the number of caribou in year $t, N_{0}$ is the number of caribou in the initial year, and $t$ is the number of years between $N_{0}$ and $N_{t}$ (Caughley 1977).

\section{Pregnancy rates and recruitment}

Over a portion of the whole sampling period, blood samples were collected during capture from 134 adult female caribou (>2.5 years old) over different years and subpopulations. Pregnancy rates were estimated from serum progesterone levels. We used a threshold progesterone value of $7 \mathrm{nmol} \cdot \mathrm{L}^{-1}$ to assess pregnancy status of caribou. Ropstad et al. (1999) have shown that plasma progesterone levels lower than $7 \mathrm{nmol} \cdot \mathrm{L}^{-1}$ rarely occur in female reindeer (Rangifer tarandus tarandus (L., 1758)) diagnosed as pregnant either by ultrasound or by observation of a calf at foot 7 months after blood sampling. In addition, the accuracy of pregnancy status assessments in our study should be even greater because we determined pregnancy rates in late March, when regular oestrus cycling of nonpregnant caribou is unlikely to occur. We used log-likelihood ratios to determine whether pregnancy rates differed among subpopulations.

We estimated calf recruitment in each subpopulation from the proportion of calves counted during aerial censuses in 


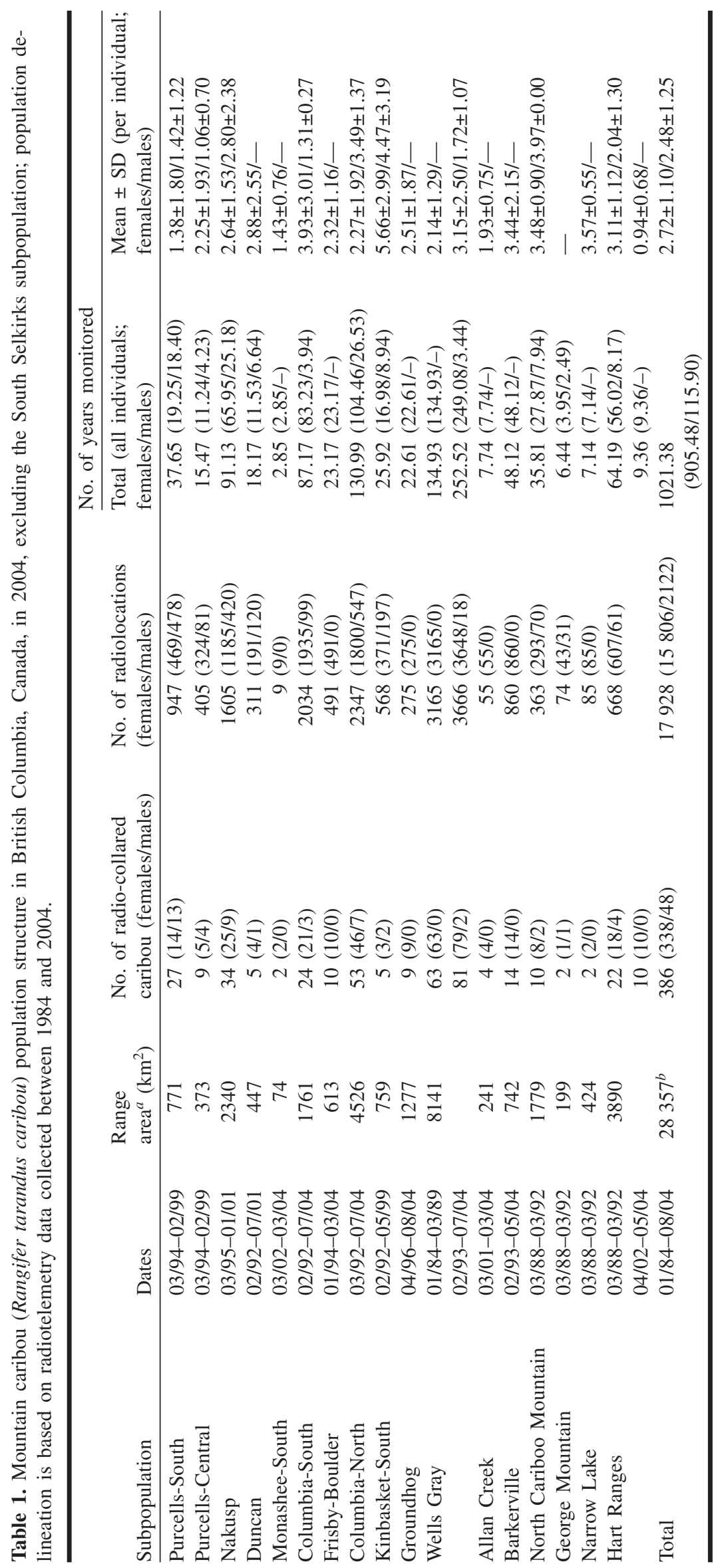


late March. We consider this proportion to be a true measure of recruitment because calves were $\approx 10$ months old in late March, and animals of that age likely experience the same mortality rates as older animals (Bergerud 1980; Fuller and Keith 1981). We used log-likelihood ratios to determine whether average recruitment rates differed among subpopulations.

\section{Cause of mortality}

When the signal from a motion-sensitive radio collar indicated that a caribou was dead, the site was investigated as soon as possible. The cause of mortality was determined from evidence found at the site and, when possible, from a necropsy that included a measurement of bone marrow, visceral, and rump fat deposits. Predation was suggested when there was evidence of bleeding, a struggle, or bite injuries. These cases were usually clear when there was snow on the ground, but less so during the summer. Cases of predation were then divided into wolf, bear, cougar, wolverine, or unknown predator based on tracks, scat, hair, and distribution and nature of the carcass. Deaths not attributed to predation were divided into those caused by accidents (i.e., avalanches, birthing, falls), malnutrition, humans, or unknown causes. In many cases it was difficult to determine the cause of death and we conservatively classified the cause as unknown.

Mortalities were grouped by summer (11 June to 21 October), early winter ( 22 October to 11 January), late winter (12 January to 23 April), and spring (24 April to 20 May) seasons. These seasons were based on average dates of elevational movements of caribou in the Columbia Mountains, since such movements are more distinctive here than in other areas (Apps et al. 2001). The calving season was from the first (21 May) to the last (10 June) day that radiocollared female caribou in the Columbia Mountains were observed with new calves. We tested for seasonal differences in the probability of dying, adjusted for season length, for all natural mortality causes (i.e., excluding human-caused mortalities) and for predator-caused mortalities only using loglikelihood ratios.

\section{Adult survival}

We used the staggered entry Kaplan-Meier procedure (Pollock et al. 1989) to calculate yearly survival rates of radio-collared adults. We based the survival intervals on the 2-week monitoring intervals and began calculations at the beginning of the calving season. Subpopulations were included in the analysis when $\geq 4$ individuals per year were monitored during at least 3 complete years. We tested for differences in average multiyear survival rates among subpopulations using a one-way ANOVA (Zar 1999). We then estimated finite rates of population increase $(\lambda)$ as a function of both recruitment and female adult survival using linear regression techniques (Zar 1999).

\section{Statistical analyses}

We used $\alpha=0.05$ for all statistical analyses. Statistical analyses were performed using SAS (SAS Institute Inc. 1995) and SYSTAT ${ }^{\circledR}$ (Systat Software Inc. 2002). Unless otherwise noted, means are reported $\pm 1 \mathrm{SE}$ of the mean.

\section{Results}

\section{Subpopulation delineation}

Based on MCP home ranges of all collared caribou, we were able to identify 17 subpopulations of mountain caribou in British Columbia (excluding the South Selkirks subpopulation). The apparent population fragmentation is most pronounced towards the southern limit of mountain caribou distribution in British Columbia (Fig. 1). Using the fixed kernel estimator, we determined that subpopulation ranges varied in size from $74 \mathrm{~km}^{2}$ for the Monashee subpopulation to $8141 \mathrm{~km}^{2}$ for the Wells Gray subpopulation. All 17 subpopulations combined covered $28357 \mathrm{~km}^{2}$ (Table 1).

\section{Subpopulation size and trend}

During all censuses between 1992 and 2004, 354 of 407 $(87 \%)$ collared caribou were observed. Sightability of collared animals over 11 census years did not differ among years $(n=56$ censuses, $G=13.715$, df $=10, P=0.186)$. Thus, in cases where no collared caribou were present to account for sightability during a census, we applied a constant correction factor of $87 \%$ to the census result to estimate population size. By using this constant correction factor, we may be underestimating population trends in subpopulations without collared animals during the 2002 or 2004 censuses because of slight differences in sightability between the initial $(92 \%)$ and current $(86 \%)$ census periods (Table 2).

All subpopulations were censused in either 2002 or 2004, resulting in a current total population estimate of 1540 mountain caribou (Table 2). The time interval between initial and current population estimates differed among subpopulations and varied between 3 and 10 years. However, the average $\lambda$ for each subpopulation weighted by the initial subpopulation estimate resulted in an overall average $\lambda$ of 0.92. Trends in individual subpopulations varied, with more southern ones generally decreasing more rapidly than northern ones, of which some were relatively stable (Table 2). Currently, estimated population sizes of 8 of 17 subpopulations are $\leq 25$ individuals.

\section{Pregnancy rates and recruitment}

Pregnancy rates were determined from 134 adult female caribou in 8 subpopulations over 11 different years (Table 3). Plasma progesterone levels indicated that 123 of the 134 were pregnant. There were no apparent trends in pregnancy rates among years within subpopulations. We did not detect differences in pregnancy rates among subpopulations when data were pooled over years $(G=2.921$, df $=7, P=$ 0.892 ). The overall pregnancy rate of mountain caribou was $92.40 \% \pm 2.24 \%$.

Long-term averages of the percentage of calves in March (when calves were $\approx 10$ months old) varied among subpopulations, ranging between $0 \%$ and $23.40 \%$ with a mean of $11.57 \% \pm 1.50 \%$ (Table 4 ). The coefficient of variation $(\mathrm{CV})$ of the observed percentage varied from 0 to 244.95 (mean $=49.38 \pm 16.09)$ within subpopulations.

\section{Cause of mortality}

Between 1984 and 2004, 165 mortalities of radio-collared caribou were recorded in 15 of the 17 subpopulations. Deaths of 6 caribou ( 3 females and 3 males) were caused by hu- 
Fig. 1. Map of study area showing current distribution and population delineation (from telemetry data using 95\% fixed kernel utilization distributions) of identified subpopulations of mountain caribou (Rangifer tarandus caribou) in British Columbia, Canada: SS, South Selkirks; PS, Purcells-South; PC, Purcells-Central; NA, Nakusp; DU, Duncan; MS, Monashee-South; CS, Columbia-South; FB, Frisby-Boulder; CN, Columbia-North; KS, Kinbasket-South; GH, Groundhog; WG, Wells Gray; AC, Allan Creek; BV, Barkerville; NC, North Cariboo Mountain; GM, George Mountain; NL, Narrow Lake; and HR, Hart Ranges.

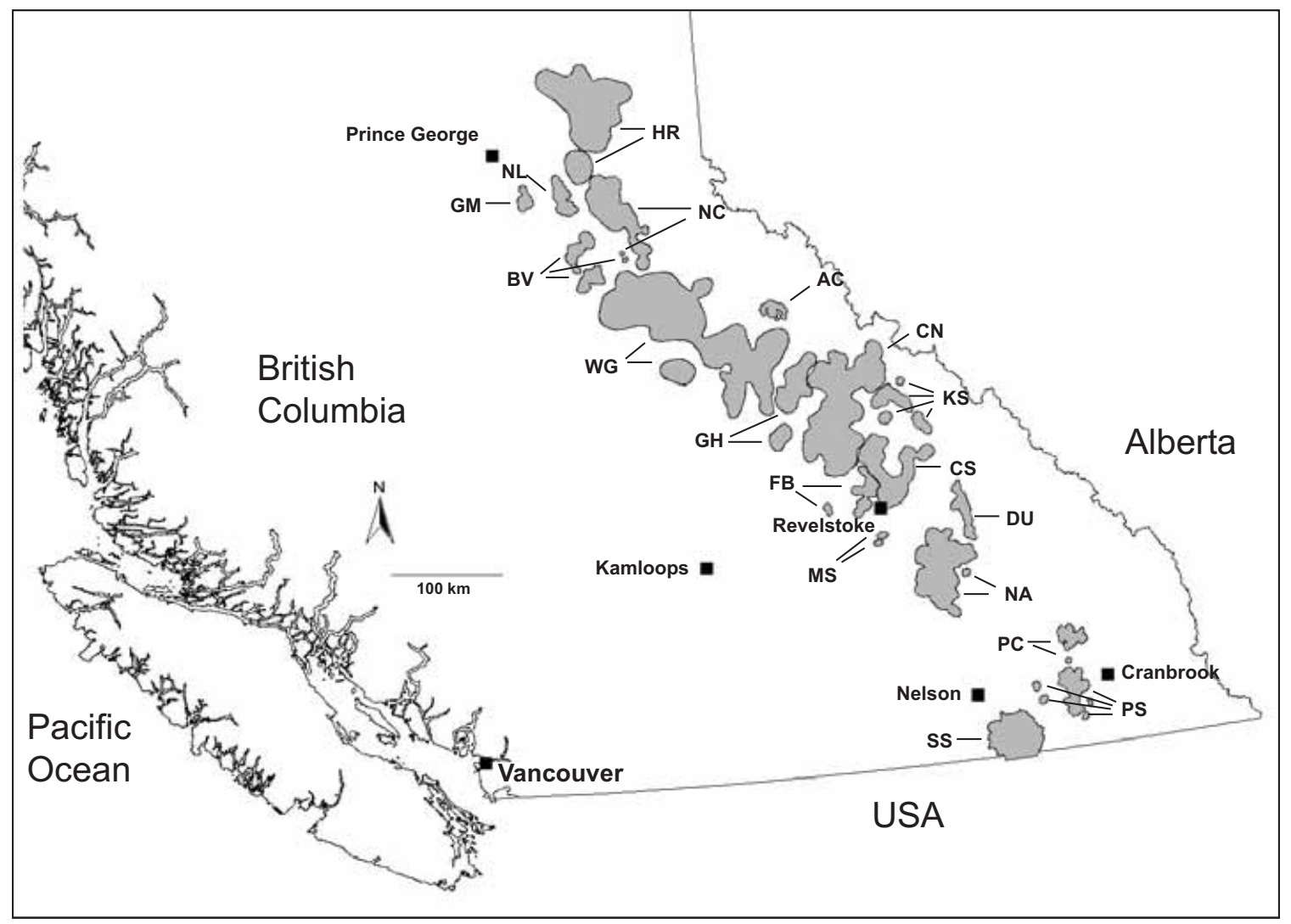

mans: 2 caribou died as a result of vehicle accidents, 2 suffered research-related mortalities, and 2 were illegally shot. Of the 159 natural mortalities, we could confidently categorize 98 as being due to predation, body condition, or accidents, while 61 remained unknown. Of the 98 caribou with a known cause of death, 91 were females. Sixty-two $(68 \%)$ of these were killed by predators, $19(21 \%)$ died because of accidents, and 10 (11\%) died because of poor body condition. Of the 7 males with known causes of death, 5 were killed by predators, $1(14 \%)$ died following an accident, and $1(14 \%)$ died owing to poor body condition. Causes of death data were pooled over sexes because the ranks of mortality causes were the same.

When adjusted for season length, the frequency of natural mortality causes differed among seasons $(G=20.064$, df $=$ 4, $P<0.001$ ), with caribou being more likely to die during the calving and summer seasons (Fig. 2). Caribou are also more likely to die because of predation during calving and summer than during other seasons $(G=23.105$, df $=4, P<$ 0.001 ). Due to small samples, we pooled the 17 subpopulations into northern and southern groups, with the division at the Groundhog-Columbia-North boundary. We found similar known causes of mortality in each group; however, wolves and bears were the major predators in the north, while cougar, bears, and wolverine were the major predators in the south (Fig. 3).

\section{Adult survival}

Too few males were sampled to compare survival rates between sexes. The sample size of female caribou was sufficient in 10 of 17 subpopulations. Multiyear average survival rates varied between $0.55 \pm 0.10$ in the Purcells-South subpopulation and $0.96 \pm 0.03$ in the Hart Ranges subpopulation and were significantly different among subpopulations (one-way ANOVA, $F_{[10,292]}=3.306, P=0.021$ ) $($ Table 5). Annual survival rates also varied considerably among years within subpopulations (CV ranges from 6.03 to 37.22 ).

We assessed the contributions of adult survival and recruitment to $\lambda$ using data from 10 subpopulations where estimates of both vital rates were available. Trends in individual subpopulations were significantly correlated with mean annual survival rates of females (GLM, $R^{2}=0.713$, $\left.F_{[1,9]}=19.874, P=0.002\right)$, with subpopulations with the lowest female survival rates declining at the fastest rate. Variation in rates of increase was not correlated with calf recruitment estimated from multi-annual mean percentages of calves at $\approx 10$ months of age (GLM, $R^{2}=0.135, F_{[1,9]}=$ 1.250, $P=0.296)$.

\section{Discussion}

The distribution and abundance of mountain caribou in British Columbia has contracted greatly over the past cen- 


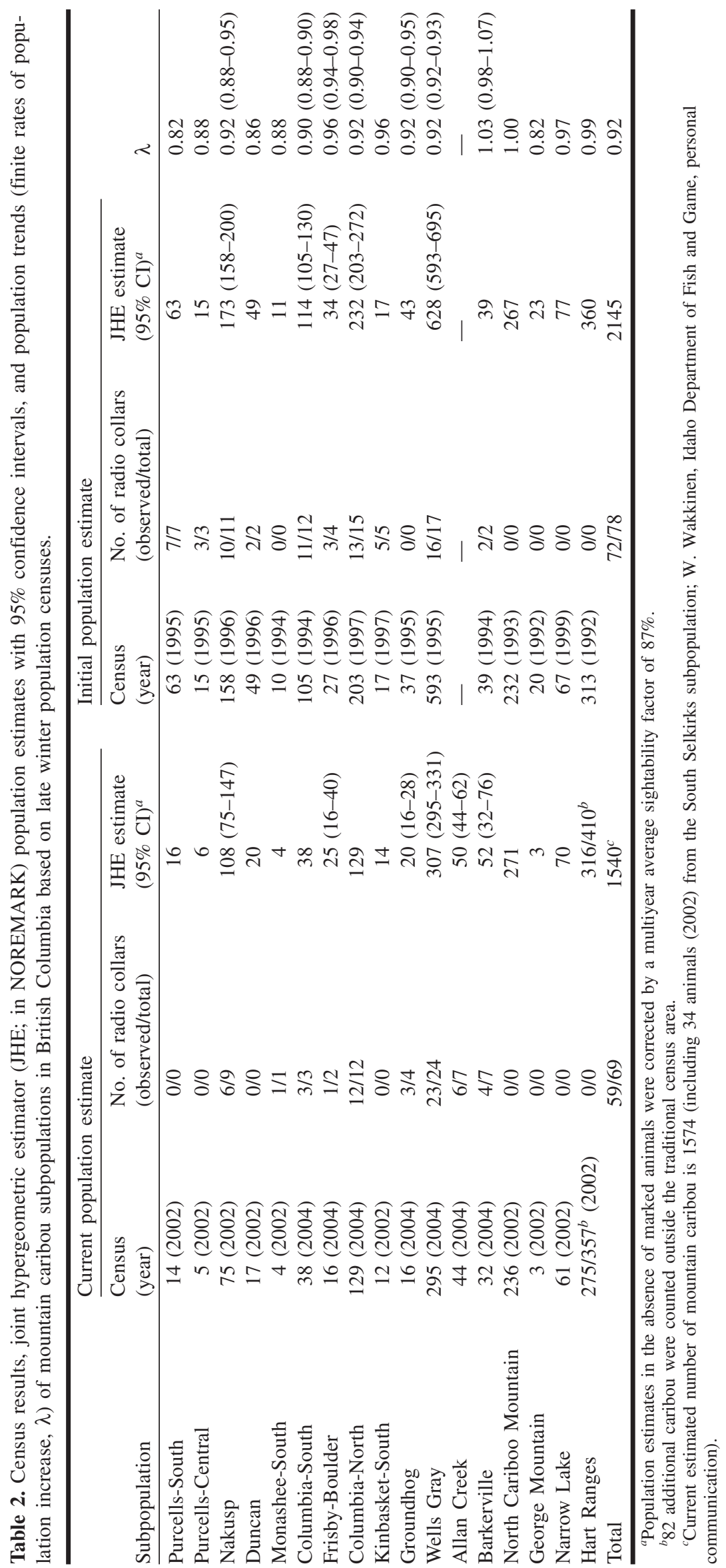


Table 3. Pregnancy rates (number of pregnant females / animal sample) among 134 adult female mountain caribou ( $>2.5$ years old) in British Columbia from 1984 to 1997, determined from serum progesterone levels and presented by subpopulation and year.

\begin{tabular}{|c|c|c|c|c|c|c|c|c|}
\hline Year & $\begin{array}{l}\text { Purcells- } \\
\text { South }\end{array}$ & $\begin{array}{l}\text { Purcells- } \\
\text { Central }\end{array}$ & Duncan & $\begin{array}{l}\text { Columbia- } \\
\text { South }\end{array}$ & $\begin{array}{l}\text { Columbia- } \\
\text { North }\end{array}$ & $\begin{array}{l}\text { Kinbasket- } \\
\text { South }\end{array}$ & Wells Gray & Barkerville \\
\hline 1984 & & & & & & & $1.00(12 / 12)$ & \\
\hline 1985 & & & & & & & $1.00(6 / 6)$ & \\
\hline 1986 & & & & & & & $0.89(24 / 27)$ & \\
\hline 1987 & & & & & & & $1.00(4 / 4)$ & \\
\hline 1988 & & & & & & & $1.00(1 / 1)$ & \\
\hline 1994 & $1.00(4 / 4)$ & $1.00(3 / 3)$ & & & & & $1.00(4 / 4)$ & \\
\hline 1995 & & & & & & & $1.00(4 / 4)$ & \\
\hline 1996 & & & & & & & $1.00(5 / 5)$ & $1.00(1 / 1)$ \\
\hline 1997 & $0.75(3 / 4)$ & $0.67(2 / 3)$ & & & $0.75(3 / 4)$ & $1.00(1 / 1)$ & $1.00(6 / 6)$ & $0.67(2 / 3)$ \\
\hline Mean \pm SE & $0.88 \pm 0.13$ & $0.84 \pm 0.17$ & $1.00 \pm 0.00$ & $0.94 \pm 0.06$ & $0.88 \pm 0.07$ & $1.00 \pm 0.00$ & $0.98 \pm 0.02$ & $0.89 \pm 0.11$ \\
\hline
\end{tabular}

tury (Spalding 2000), and it appears that trend is continuing. Over the past 21 years, several subpopulations have experienced significant reductions and are in imminent danger of extinction. The spatial pattern of decline is for the population to become increasingly fragmented into small, isolated subpopulations. Isolation of subpopulations is most pronounced towards the southern limit of the distribution of mountain caribou, but population fragmentation occurs at both the southern limit and the outer boundary of the distribution. This increasing fragmentation of mountain caribou into discrete subpopulations with limited interaction is consistent with previous observations of woodland caribou (Stuart-Smith et al. 1997; Rettie and Messier 1998) and is likely to accelerate the extinction process by increasing risks associated with demographic and environmental stochasticity (Caughley 1994). Although population extinction and recolonization is the basis of metapopulation theory (Hanski and Gilpin 1991), the trend in the range contraction from the outer boundaries of mountain caribou distribution suggests a directional change in conditions that could result in extinction.

Estimates of mean annual adult survival rates of woodland caribou in North America commonly range from 0.84 to 0.93 (Bergerud 1980; Fuller and Keith 1981; Stuart-Smith et al. 1997; Rettie and Messier 1998; Mahoney and Virgl 2003). The survival rates we observed in some subpopulations during this study are substantially lower than nearly all previously reported estimates for woodland caribou except those found in one other rapidly declining population (i.e., 0.70 year $^{-1}$; Schaefer et al. 1999). We found considerable temporal variation in adult female survival $(\mathrm{CV}>10)$ in all but the two subpopulations at the northern limit of mountain caribou distribution in British Columbia. High levels of temporal variation in adult female survival have previously been observed in declining caribou populations (Schaefer et al. 1999). Gasaway et al. (1992) suggested that such temporal variation in adult survival in ungulates may be associated with high levels of predation from predators that are primarily sustained by an alternative prey species. In addition, our results revealed differences in mean adult survival rates of female mountain caribou among subpopulations. The spatial and temporal variability in adult survival rates in this study is different from that generally reported for large herbivores
(Gaillard et al. 2000) and indicates that data sampled from large, viable populations may not adequately reflect the dynamics of small, declining populations.

Pregnancy rates in this study were high and did not differ among subpopulations. The relative consistency of pregnancy rates irrespective of population trajectory appears typical for woodland caribou (Schaefer et al. 1999) and most other ungulates, with the exception of increasing age of primiparity with increasing population density (Gaillard et al. 2000). Rettie and Messier (1998) suggested that this insensitivity implies an absence of nutritional factors in population decline and thus indicates a potential for population recovery. Unlike pregnancy rates, average calf recruitment rates were low. Although recruitment rates in some subpopulations fall within the range suggested to result in stable caribou populations (12\%-16\% calves, 10-12 months old) (Bergerud 1974), recruitment observed in this study is inadequate to balance high adult mortality rates. In addition, recruitment rates showed temporal variation similar to that of adult female survival rates, suggesting that recruitment may be linked to adult survival by a common mortality agent, presumably predation (Seip and Cichowski 1996; Schaefer et al. 1999).

The major proximate cause of population decline of mountain caribou appears to be predation on adult caribou, but identified primary predators differed between northern and southern subpopulations. In northern subpopulations, wolf and bear predation were the dominant causes of death. Recent studies of woodland caribou have stressed the importance of alternative ungulate prey, primarily moose, leading to greater wolf numbers and increased predation on caribou (Bergerud and Elliot 1986; Seip 1992; Schaefer et al. 1999; Rettie and Messier 2000). In such a predator-prey system, the numerical response of wolves becomes independent of caribou densities and caribou can persist only where they can separate themselves from alternative prey species (Seip 1992; Rettie and Messier 2000). Although bears have been identified as an important source of mortality of caribou calves (e.g., Adams et al. 1995; Mahoney and Virgl 2003), our results suggest that bear predation on adults may also be an important limiting factor, especially because bear predation is likely additive to wolf predation.

In southern mountain caribou subpopulations, bear, wolverine, and particularly cougar predation were the predomi- 


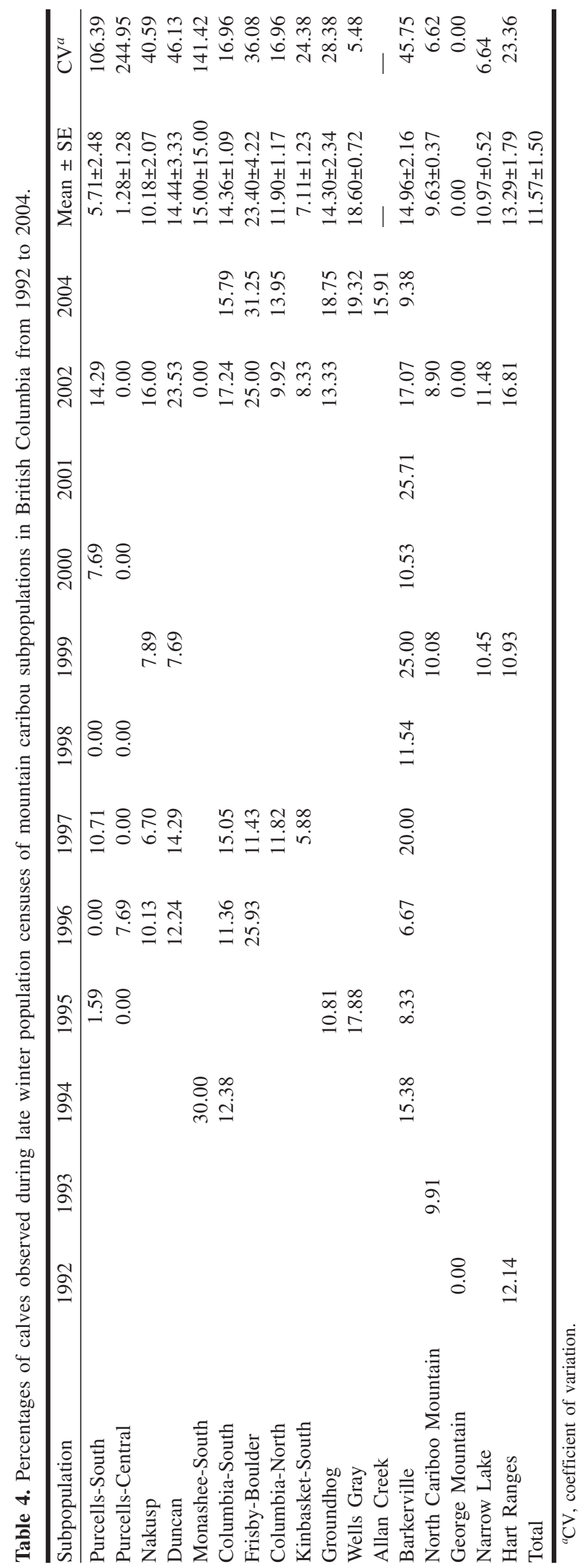

Fig. 2. Pooled (females and males) proportions of mountain caribou that died of natural causes during calving (21 May - 10 June), summer (11 June - 21 October), early winter (22 October 11 January), late winter (12 January - 23 April), and spring (24 April - 20 May) seasons in British Columbia. Proportions were adjusted for season length (days); labels above the bars indicate total number of mortalities.

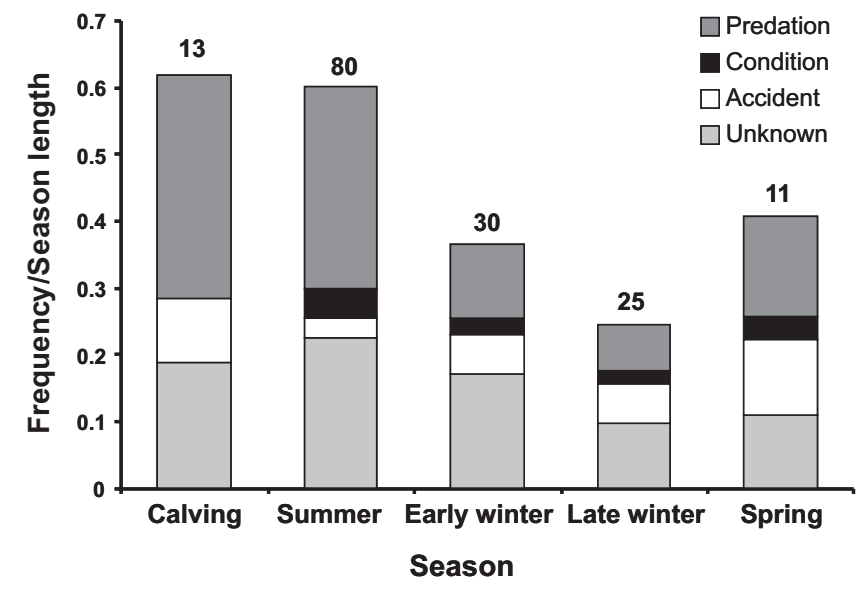

Fig. 3. Pooled (females and males) mountain caribou mortalities caused by identified predator species in the northern and southern parts of mountain caribou distribution in British Columbia.

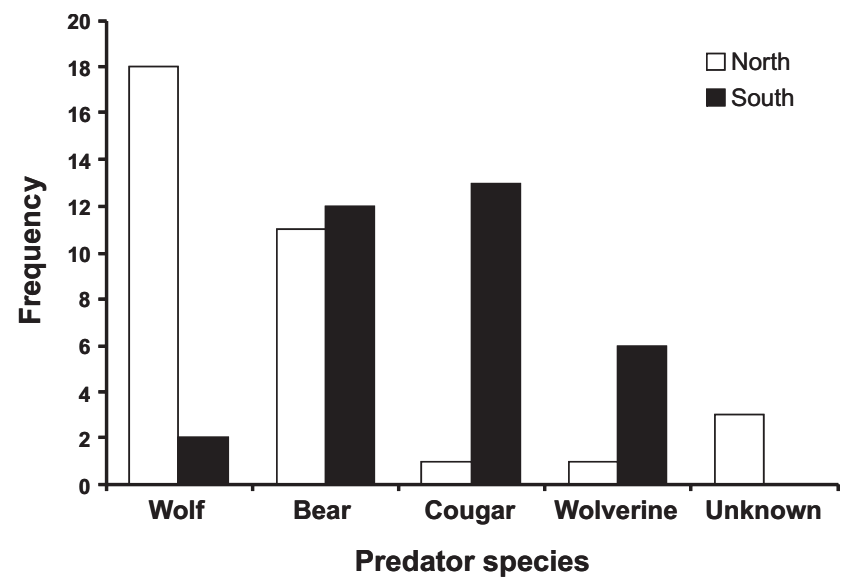

nant causes of death. We suggest that the large mammal predator-prey system in southern British Columbia may also have been disrupted. Successful game animal management, focusing on white-tailed deer, mule deer, and elk, may have stimulated an increase in cougar numbers and a resulting increase in predation on caribou. Effects of changes in the predator-prey system may have been influenced by habitat alterations that increased the amount and distribution of early seral habitats preferred by deer and elk (Kinley and Apps 2001). All nine identified subpopulations in this predator-prey environment showed negative population trajectories. This absence of population growth over the entire distribution suggests changes in the predator-prey system at large spatial scales and indicates that mountain caribou may not be viable in the current predator-prey environment without the use of predator control.

As in other woodland caribou populations where predation was the primary cause of adult mortality, the majority of mortalities in this study occurred during summer (Stuart- 


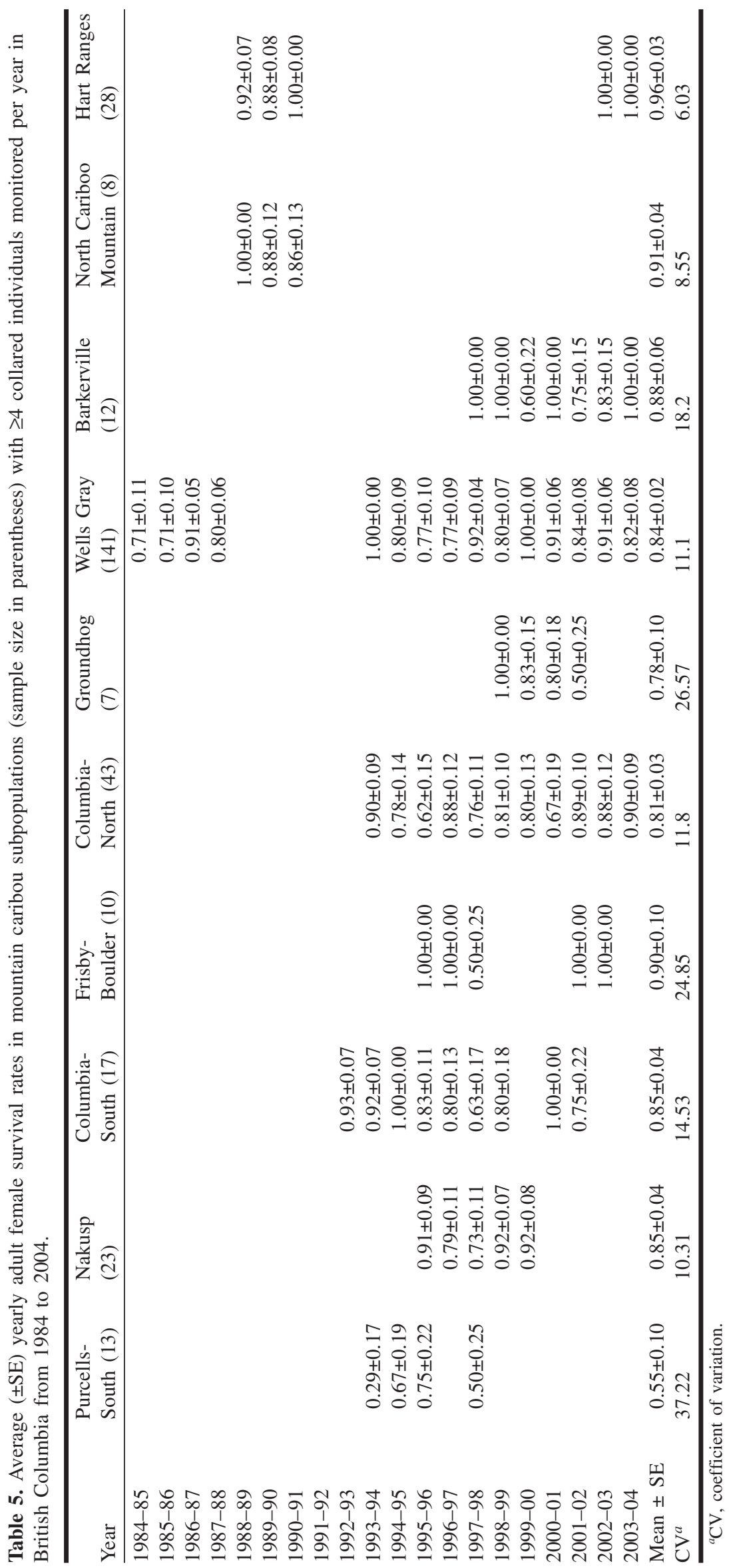


Smith et al. 1997; Rettie and Messier 1998). The low mortality rates we observed during winter are likely a consequence of both species of bears hibernating during winter and caribou being spatially separated from most other predators at this time of year. Mountain caribou move from lower elevations in early winter to higher elevations in late winter (Seip 1992; Apps et al. 2001). These elevational movements are influenced by snow conditions. As the snowpack deepens (2-5 $\mathrm{m}$ deep) and consolidates later in winter, it provides a platform from which caribou can access arboreal lichen directly in the forest canopy on high-elevation, latewinter ranges. In addition to the increased food availability, these high-elevation, late-winter ranges are rarely used by predators that are preying on other species that seek areas with shallow snowpacks.

\section{Implications for mountain caribou conservation}

The decline of mountain caribou due to high predation rates appears to be a result of major environmental changes. It is probable that a variety of factors, including colonization by alternative prey such as moose since the early 1900s, landscape changes due to forest management, management efforts to increase other cervid populations, and changes in predator management policy, have contributed to ecosystemwide changes in the large mammal predator-prey system. In such an altered ecosystem, predators can cause extinction when they incidentally kill rare prey species while depending on other primary prey species (Sinclair et al. 1998). The significance of such changes in predator-prey systems and the resulting declines of endangered species have recently received increased attention. Courchamp et al. (2003), for example, have linked the decline of an endangered island gray fox (Urocyon littoralis (Baird, 1857)) population to increased predation from golden eagle (Aquila chrysaetos (L., 1758)) preying mainly on abundant introduced feral pigs (Sus scrofa L., 1758). They suggest that successful recovery efforts for foxes must address both alternative prey abundance and predator abundance. The similar importance of alternative prey and predator abundances in the decline of mountain caribou suggests that recovery of mountain caribou will also require a multispecies perspective.

Some of the factors altering the predator-prey system, such as changes to the forest age structure, likely cannot be rectified in time to maintain mountain caribou. Other factors, however, can be changed. Although overall numbers of some predators and their prey can be changed through hunting regulations, it has been suggested that some individual cougars (Katnik 2002) and specific wolf packs kill a disproportionate number of caribou. If this hypothesis can be validated, localized reductions of cougars and wolves where predation of caribou is high might be an effective management strategy to reduce the impact of predators on caribou populations. However, given the likelihood that changes in the predator-prey system have occurred and continue to occur over large areas of the distribution of mountain caribou, it is possible that the remaining subpopulations are no longer viable without continued management of predators. There are practical and ethical difficulties inherent in seeking to kill predators (National Research Council 1997; Courchamp et al. 2003) as a means of protecting rare species, so we must address the question of whether mountain caribou re- covery is acceptable if ongoing predator control is required to maintain them.

Given the objective that mountain caribou conservation is the policy priority, other conservation strategies should be explored. Along with predator management, reduction of alternative prey levels through increased hunting should be considered. In addition, guidelines for the management of alternative ungulates need to address the priority of caribou conservation. Active implementation of management strategies that discourage increases in other ungulate populations is required. Although reactive policies such as translocations have not resulted in an increase in the size of the transboundary South Selkirks subpopulation (Compton et al. 1995), even with the control of predators, several of the smallest subpopulations may become extirpated without augmentation with additional animals.

\section{Acknowledgements}

This project was funded by the British Columbia Ministries of Forests and Water, Land and Air Protection, Columbia Basin Fish and Wildlife Compensation Program, Parks Canada, Forest Renewal British Columbia, and numerous forestry companies that operate across the range of mountain caribou. H.U. Wittmer was supported by fellowships from the International Council for Canadian Studies, the University of British Columbia, and the Faculty of Agricultural Sciences at the University of British Columbia. We are thankful to the numerous people involved in data collection, often under difficult conditions. F. Hovey provided helpful comments on the statistical analyses. J. Brashares, M. FestaBianchet, J.-M. Gaillard, D. Shackleton, and an anonymous reviewer provided insightful comments on earlier drafts of this paper.

\section{References}

Adams, L.G., Singer, F.J., and Dale, B.W. 1995. Caribou calf mortality in Denali National Park, Alaska. J. Wildl. Manag. 48: 584-594.

Apps, C.D., McLellan, B.N., Kinley, T.A., and Flaa, J.P. 2001. Scale-dependent habitat selection by mountain caribou, Columbia Mountains, British Columbia. J. Wildl. Manag. 65: 65-77.

Bartmann, R.M., White, G.C., Carpenter, L.H., and Garrott, R.A. 1987. Aerial mark-recapture estimates of confined mule deer in pinyon-juniper woodland. J. Wildl. Manag. 51: 41-46.

Bergerud, A.T. 1974. Decline of caribou in North America following settlement. J. Wildl. Manag. 38: 757-770.

Bergerud, A.T. 1980. A review of the population dynamics of caribou and wild reindeer in North America. In Proceedings of the 2nd International Reindeer/Caribou Symposium, Røros, Norway, September 1979. Edited by E. Reimers, E. Gaare, and S. Skjenneberg. Direktoratet for vilt og ferskvannsfisk, Trondheim, Norway. pp. 556-581.

Bergerud, A.T. 1996. Evolving perspectives on caribou population dynamics, have we got it right yet? Rangifer Spec. Issue, 9: 95116.

Bergerud, A.T., and Elliot, J.P. 1986. Dynamics of caribou and wolves in northern British Columbia. Can. J. Zool. 64: 15151529.

British Columbia Conservation Data Centre. 2001. Provincial vertebrate animal tracking list. Ministry of Environment, Lands and Parks, Victoria, B.C. 
Caughley, G. 1977. Analysis of vertebrate populations. John Wiley and Sons, Toronto.

Caughley, G. 1994. Directions in conservation biology. J. Anim. Ecol. 63: 215-244.

Compton, B.B., Zager, P., and Servheen, G. 1995. Survival and mortality of translocated woodland caribou. Wildl. Soc. Bull. 23: 490-496.

COSEWIC. 2002. COSEWIC assessment and update status report on the woodland caribou Rangifer tarandus caribou in Canada. Committee on the Status of Endangered Wildlife in Canada, Ottawa, Ont.

Courchamp, F., Woodroffe, R., and Roemer, G. 2003. Removing protected populations to save endangered species. Science (Wash., D.C.), 302: 1532.

Environment Canada. 2002. Canadian climate normals 1961-2000. Environment Canada, Ottawa, Ont.

ESRI. 1996. ArcView ${ }^{\circledR}$. Version 3.2 [computer program]. Environmental Systems Research Institute, Inc., Redlands, Calif.

Fuller, T.K., and Keith, L.B. 1981. Woodland caribou population dynamics in northeastern Alberta. J. Wildl. Manag. 45: 197-213.

Gaillard, J.-M., Festa-Bianchet, M., Yoccoz, N.G., Loison, A., and Toïgo, C. 2000. Temporal variation in fitness components and population dynamics of large herbivores. Annu. Rev. Ecol. Syst. 31: $367-393$.

Gasaway, W.C., Boertje, R.D., Grangaard, D.V., Kelleyhouse, D.G., Stephenson, R.O., and Larsen, D.G. 1992. The role of predation in limiting moose at low densities in Alaska and Yukon and implications for conservation. Wildl. Monogr. No. 120: 1-59.

Hanski, I., and Gilpin, M.E. 1991. Metapopulation dynamics: brief history and conceptual domain. Biol. J. Linn. Soc. 42: 3-16.

Hatter, I., Butler, D., Fontana, A., Hebert, D., Kinley, T., McNay, S. et al. 2002. A strategy for the recovery of mountain caribou in British Columbia. Ministry of Water, Land and Air Protection, Victoria, B.C. Available from http://wlapwww.gov.bc.ca/ wld/pub/pub.htm.

Heard, D.C., and Vagt, K.L. 1998. Caribou in British Columbia: a 1996 status report. Rangifer Spec. Issue, 10: 117-123.

Hooge, P.N., and Eichenlaub, B. 2000. Animal movement extension to ArcView. Version 2.0 [computer program]. Alaska Science Center - Biological Science Office, US Geological Survey, Anchorage, Alaska.

James, A.R.C., and Stuart-Smith, A.K. 2000. Distribution of caribou and wolves in relation to linear corridors. J. Wildl. Manag. 64: 154-159.

Katnik, D.D. 2002. Predation and habitat ecology of mountain lions (Puma concolor) in the Southern Selkirk Mountains. Ph.D. thesis, Washington State University, Pullman, Wash.

Kinley, T.A., and Apps, C.D. 2001. Mortality patterns in a subpopulation of endangered mountain caribou. Wildl. Soc. Bull. 29: $158-164$.

Mahoney, S.P., and Virgl, J.A. 2003. Habitat selection and demography of a nonmigratory woodland caribou population in Newfoundland. Can. J. Zool. 81: 321-334.

Meidinger, D.V., and Pojar, J. 1991. Ecosystems of British Columbia. Special Report Series 4. British Columbia Ministry of Forests, Victoria, B.C.

Mohr, C.O. 1947. Table of equivalent populations of North American small mammals. Am. Midl. Nat. 37: 223-249.

National Research Council. 1997. Wolves, bears, and their prey in Alaska: biological and social challenges in wildlife management. National Academies Press, Washington, D.C.

Pollock, K.H., Winterstein, S.R., Bunck, C.M., and Curtis, P.D. 1989. Survival analysis in telemetry studies: the staggered entry design. J. Wildl. Manag. 53: 7-15.
Rettie, W.J., and Messier, F. 1998. Dynamics of woodland caribou populations at the southern limit of their range in Saskatchewan. Can. J. Zool. 76: 251-259.

Rettie, W.J., and Messier, F. 2000. Hierarchical habitat selection by woodland caribou: its relationship to limiting factors. Ecography, 23: 466-478.

Rominger, E.M., and Oldemeyer, J.L. 1989. Early-winter habitat of woodland caribou, Selkirk Mountains, British Columbia. J. Wildl. Manag. 53: 238-243.

Rominger, E.M., Robins, C.T., and Evans, M.A. 1996. Winter foraging ecology of woodland caribou in northeastern Washington. J. Wildl. Manag. 60: 719-728.

Ropstad, E., Johansen, O., King, C., Dahl, E., Albon, S.D., Langvatn, R.L. et al. 1999. Comparison of plasma progesterone, transrectal ultrasound and pregnancy specific proteins (PSPB) used for pregnancy diagnosis in reindeer. Acta Vet. Scand. 40: $151-162$.

SAS Institute Inc. 1995. SAS user's guide. Version 6.4. SAS Institute Inc., Cary, N.C.

Schaefer, J.A., Veitch, A.M., Harrington, F.H., Brown, W.K., Theberge, J.B., and Luttich, S.N. 1999. Demography of decline of the Red Wine Mountains caribou herd. J. Wildl. Manag. 63: 580-587.

Seip, D.R. 1992. Factors limiting woodland caribou populations and their interrelationship with wolves and moose in southeastern British Columbia. Can. J. Zool. 70: 1494-1503.

Seip, D.R., and Cichowski, D.B. 1996. Population ecology of caribou in British Columbia. Rangifer Spec. Issue, 9: 73-80.

Sinclair, A.R.E., Pech, R.P., Dickman, C.R., Hik, D., Mahon, P., and Newsome, A.E. 1998. Predicting effects of predation on conservation of endangered prey. Conserv. Biol. 12: 564-575.

Spalding, D.J. 2000. The early history of woodland caribou (Rangifer tarandus caribou) in British Columbia. British Columbia Ministry of Environment, Lands and Parks, Victoria, B.C.

Stevenson, S.K., Armleder, H.M., Jull, M.J., King, D.G., McLellan, B.N., and Coxson, D.S. 2001. Mountain caribou in managed forests: recommendations for managers. Wildlife report No. R-26. Ministry of Environment, Lands and Parks, Wildlife Branch, Victoria, B.C.

Stuart-Smith, A.K., Bradshaw, C.J.A., Boutin, S., Hebert, D.M., and Rippin, A.B. 1997. Woodland caribou relative to landscape patterns in northeastern Alberta. J. Wildl. Manag. 61: 622-633.

Systat Software Inc. 2002. SYSTAT ${ }^{\circledR}$ : statistics I. Version 10.2 [computer program]. Systat Software Inc.. Richmond, Calif.

Terry, E.L., McLellan, B.N., and Watts, G.S. 2000. Winter habitat ecology of mountain caribou in relation to forest management. J. Appl. Ecol. 37: 589-602.

Thomas, D.C., and Gray, D.R. 2002. Update COSEWIC status report on the woodland caribou Rangifer tarandus caribou in Canada. In COSEWIC assessment and update status report on the woodland caribou Rangifer tarandus caribou in Canada. Committee on the Status of Endangered Wildlife in Canada, Ottawa, Ont. pp. 1-98.

US Fish and Wildlife Service. 1994. Recovery plan for woodland caribou in the Selkirk Mountains. US Fish and Wildlife Service, Portland, Oreg.

White, G.C. 1996. Program NOREMARK software reference manual [online]. Available from http://www.cnr.colostate.edu/class_info/ fw663/noremark.pdf.

Worton, B.J. 1989. Kernel methods for estimating the utilization distribution in home-range studies. Ecology, 70: 164-168.

Zar, J.H. 1999. Biostatistical analysis. 4th ed. Prentice Hall, Upper Saddle River, N.J. 